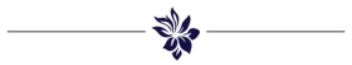

http://jurnal.unipasby.ac.id/index.php/kanigara

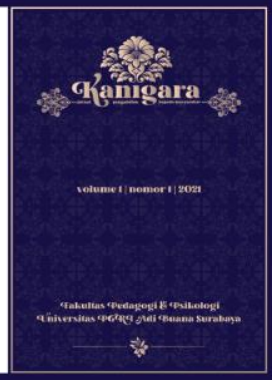

\title{
CUCI TANGAN PAKAI SABUN SALAH SATU UPAYA CEGAH PENULARAN COVID-19 BAGI GURU SMP NEGERI 1 PERAK JOMBANG
}

\author{
M. Wahyono', Shandy Pieter P2*, Angga Indra K$^{3}$, Eka Kurnia ${ }^{4}$, \\ Bayu Akbar $\mathrm{H}^{5}$, Ismawandi B.P ${ }^{6}$
}

Pendidikan Jasmani Universitas PGRI Adi Buana Suarabaya

Email: shandypieter@unipasby.ac.id

\begin{tabular}{ll}
\hline Informasi Artikel & Abstrak \\
\hline Kata kunci: & WHO (Badan Kesehatan Dunia) dan CDC (Pusat Pengendalian dan \\
Covid 19, Cuci Tangan & Pencegahan Penyakit Amerika Serikat) menghimbau masyarakat dapat \\
Pakai Sabun & mencegah penyebaran corona dengan melakukan cuci tangan dengan \\
& memakai sabun atau disebut CTPS (Cuci Tangan Pakai Sabun). Mencuci \\
& tangan menggunakan sabun merupakan sebuah tindakan personal hygine \\
& yaitu dengan membasuh tangan dan jari jemari menggunakan di bawah air \\
& mengalir dan tidak lupa harus memakai sabun agar tangan menjadi bersih \\
& serta bebas dari berbagai macam kuman. Selain itu tujuan dari CTPS adalah \\
& untuk mencegah timbulnya berbagai macam penyakit.
\end{tabular}

Abstact
WHO (World Health Organization) and CDC (Center for Disease Control and
Prevention of the United States) urge people to prevent the spread of corona by
washing their hands using soap or called CTPS (Washing Hands with Soap).
Washing hands using soap is a personal hygine action, namely by washing
hands with soap. wash your hands and fingers under running water and do
not forget to use soap so that your hands are clean and free from various kinds
of germs. In addition, the purpose of CTPS is to prevent various kinds of
diseases. 


\section{PENDAHULUAN}

Wabah covid 19 yang disebabkan oleh virus yang bernama corona berhasil menggemparkan seluruh dunia. Semua negara di belahan dunia terjangkit wabah ini, bahkan banyak sekali negara - negara yang mengalami banyak sekali korban jiwa. Virus ini menyebar sangat cepat tanpa disadari oleh banyak manusia. Mirisnya, sampai saat ini belum berhasil ditemukan vaksin yang mampu untuk mengatasi wabah penyakit ini. WHO (Badan Kesehatan Dunia) dan CDC (Pusat Pengendalian dan Pencegahan Penyakit Amerika Serikat menghimbau masyarakat dapat mencegah penyebaran corona dengan melakukan cuci tangan dengan memakai sabun atau disebut CTPS (Cuci Tangan Pakai Sabun).

Mencuci tangan menggunakan sabun adalah sebuah tindakan personal hygine yaitu dengan membasuh tangan dan sela - sela jari di bawah air mengalir dan tidak lupa harus memakai sabun agar tangan terbebas dari berbagai macam virus,bakteri maupun parasit yang berukuran mikro penyebab penyakit. Selain itu tujuan dari CTPS adalah untuk mencegah timbulnya berbagai macam penyakit. Tangan merupakan sebuah agen utama penyebab kuman berpindah dan menyebar dari orang yang satu ke orang lainnya, baik akibat kontak langsung maupun tidak langsung (menyentuh permukaan - permukaan benda).

Tangan dapat secara langsung bersentuhan dengan berbagai macam sumber penyebab penyakit seperti kotoran (baik manusia ataupun binatang), cairan tubuh (keringat, air liur, ingus) dan setelah itu tangan tersebut menyentuh benda - benda atau bahkan makanan/minuman, sehingga dengan begitu sumber - sumber penyakit seperti virus, bakteri dan parasite yang hidup dari sumber penyebab penyakit akan terbawa dan menempel pada makanan/minuman yang akan kita konsumsi.

Seringkali orang hanya mencuci tangan dengan menggunakan air saja, padahal keefektifannya dibanding mencuci tangan dengan menggunakan sabun (CPTS) sangatlah kurang untuk menghilangkan kuman penyakit yang menempel pada tangan dan jari jemari. Memang jika dihitung dengan waktu yang harus dihabiskan untuk mencuci tangan menggunakan sabun membutuhkan waktu yang lama dan terbilang kurang praktis tetapi jika dilihat pada dampak baik yang akan ditimbulkan pasti setiap orang akan berfikir lagi dan memilih mencuci tanga menggunakan sabun (CPTS). Sabun akan membantu untuk melepaskan lemak dan kotoran yang menempel pada tangan.

Syarat wajib mencuci tangan adalah mencuci tangan menggunakan sabun dan di bawah air yang mengalir. Waktu cuci tangan yang baik adalah minimal 20 detik. Sebelum melakukan 
cuci tangan jangan menyentuh hidung, mulut dan mata.

Enam langkah mencuci tangan yang benar adalah :

1. Tuang sabun pada telapak tangan, ratakan dan usap telapak tangan secara lembut dengan arah memutar.

2. Usap - usap punggung tangan kanan dan kiri dengan bergiliran.

3. Usap - usap sela-sela jari tangan kanan dan kiri sampai bersih.

4. Basuh pucuk jari bergiliran dengan posisi saling mengunci.

5. Usap - usap lalu putar kedua ibu jari dengan bergiliran.

6. Posisikan pucuk jari pada telapak tangan lalu usap pelan - pelan.

Kita perlu selalu ingat bahwa tidak di setiap tempat tersedia air bersih dan sabun sehingga kita harus selalu membawa handsanitizer sebagai gantinya. Gunakanlah handsanitizer setelah memegang atau menyentuh barang dan benda sekitar kita, misal tangga, pintu kendaraan umum dll.

Dalam rangka persiapan pembelajaran luring, SMPN 1 Perak Jombang memerlukan banyak referensi tentang bagaimana cara mencegah penularan covid 19. Dimulai dari pengetahuan menjaga kebersihan dengan mencuci tangan dengan sabun. Maka dari itu, perlu diadakan penyuluhan tentang mencuci tangan pakai sabun sebagai salah satu upayan mencegah penularan covid 19 di SMPN 1 Perak Jombang.

\section{METODE}

Untuk mencapai tujuan yang diharapkan, program pengabdian masyarakat di SMP Negeri 1 Perak- Jombang, dilakukan dengan pemberdayaan para guru melalui penyuluhan untuk selalu menjaga kebersihan dengan selalu rajin mencuci tangan pakai sabun agar terhidar dan tidak tertular dari virus corona.

\begin{tabular}{|l|l|l|l|l|}
\hline No & \multicolumn{1}{|c|}{ Metode } & \multicolumn{1}{|c|}{ Kegiatan } & Durasi & \multicolumn{1}{|c|}{$\begin{array}{l}\text { Jumlah Guru yang } \\
\text { terlibat }\end{array}$} \\
\hline 1. & Perizinan & $\begin{array}{l}\text { Meminta ijin kepeda kepala SMP N 1 Perak } \\
\text { Jombang untuk melaksanakan kegiatan PPM }\end{array}$ & $1 \times 60^{\prime}$ & $\begin{array}{l}\text { Semua guru SMP N 1 } \\
\text { Perak Jombang }\end{array}$ \\
\hline 2. & Edukasi Virus Corona & Memberi wawasan terkait virus corona & $2 \times 120^{\prime}$ & $\begin{array}{l}\text { Semua guru SMP N 1 } \\
\text { Perak Jombang }\end{array}$ \\
\hline 3. & $\begin{array}{l}\text { Demontrasi Cuci } \\
\text { Tangan Pakai Sabun }\end{array}$ & $\begin{array}{l}\text { Memberikan penyuluhan cara cuci tangan } \\
\text { pakai sabun yang benar supaya tidak tertular } \\
\text { virus corona }\end{array}$ & $2 \times 120^{\prime}$ & $\begin{array}{l}\text { Semua guru SMP N 1 } \\
\text { Perak Jombang }\end{array}$ \\
\hline
\end{tabular}

\section{HASIL DAN PEMBAHASAN}

Pada kondisi pandemi saat ini, masyarakat terutama para pendidik/ guru membutuhkan banyak pengetahuan mengenai kesehatan diri dan penambahan ilmu pengetahuan tentang virus 

corona yang akan disalurkan kepada siswanya. Maka dari itu dari hal tersebut dapat diputuskan bahwa terdapat beberapa materi dari kegiatan PPM yang dapat dilakukan di SMP Negeri 1 Perak Jombang guna meningkatkan dan memberikan banyak pengetahuan, baik dari kesehatan maupun pendidikan. Terdapat beberapa meteri yang dilakukan oleh dosen, yaitu, edukasi tentang Covid 19 dan cuci tangan pakai sabun (CTPS). Materi utama kegiatan PPM ini adalah penyuluhan cuci tangan pakai sabun kepada bapak ibu guru SMPN 1 Perak Jombang.

\section{A. Mengapa Penting untuk Mencuci Tangan Pakai Sabun (CTPS)}

Sabun menyebabkan lemak, kotoran dan berbagai kuman penyakit menjadi terlepas dari tangan dan tangan terasa lebih kesat dan bersih. Kita tahu bahwa manusia selalu melakukan semua aktivitasnya dengan menggunakan tangan untuk memegang/menyentuh segala sesuatu benda yang akan digunakan. Sehingga tangan seringkali kotor terkena permukaan benda tersebut. Dan tanpa disadari mereka menggunakan tangan yang telah terkontaminasi dengan kotoran pada benda yang dipegang/disentuh untuk mengusap mata, hidung dan mulut. Oleh karena itulah diharuskan dan dianjurkan untuk selalu cuci tangan pakai sabun (CTPS) setelah memegang/menyentuh benda benda di sekitar.

\section{Prinsip-Prinsip Penting Cuci Tangan Pakai Sabun (CTPS):}

1. Cucilah tangan menggunakan sabun dan air yang mengalir.

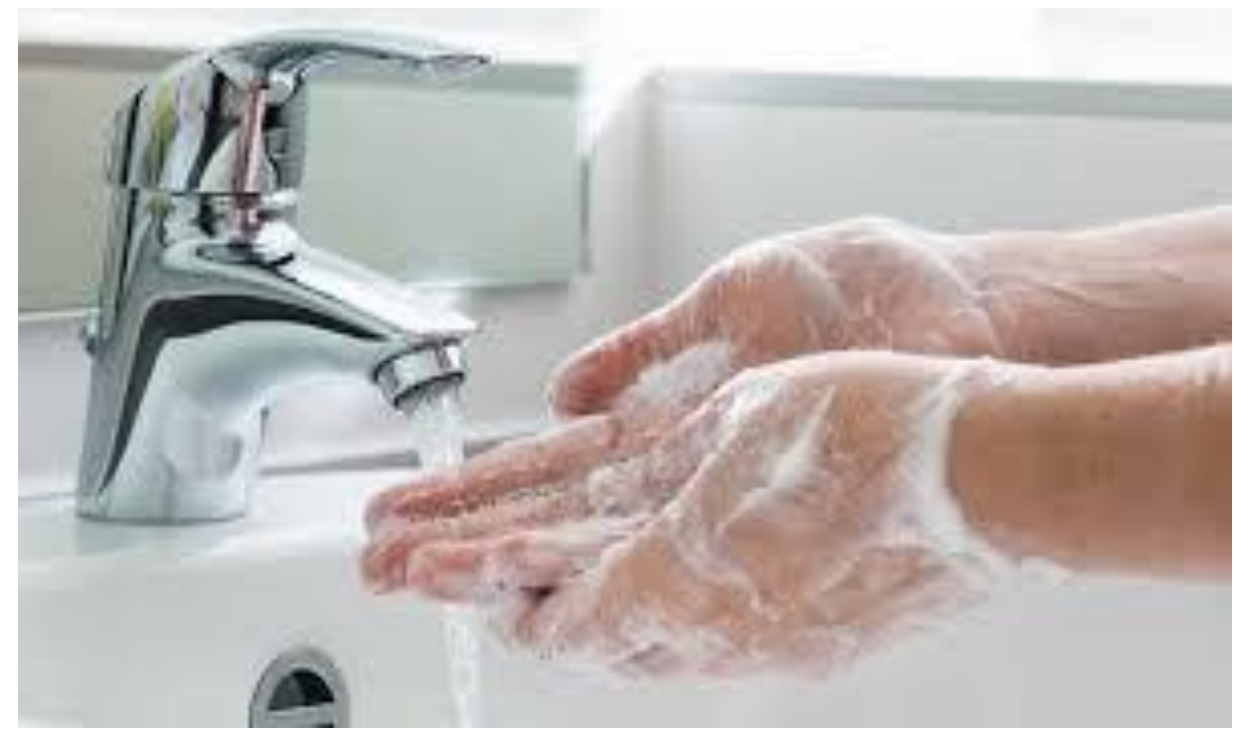


2. cucilah tangan pakai sabun (CTPS) dengan waktu minimal 40-60 detik dengan melaksanakan 6 langkah cuci tangan dengan benar

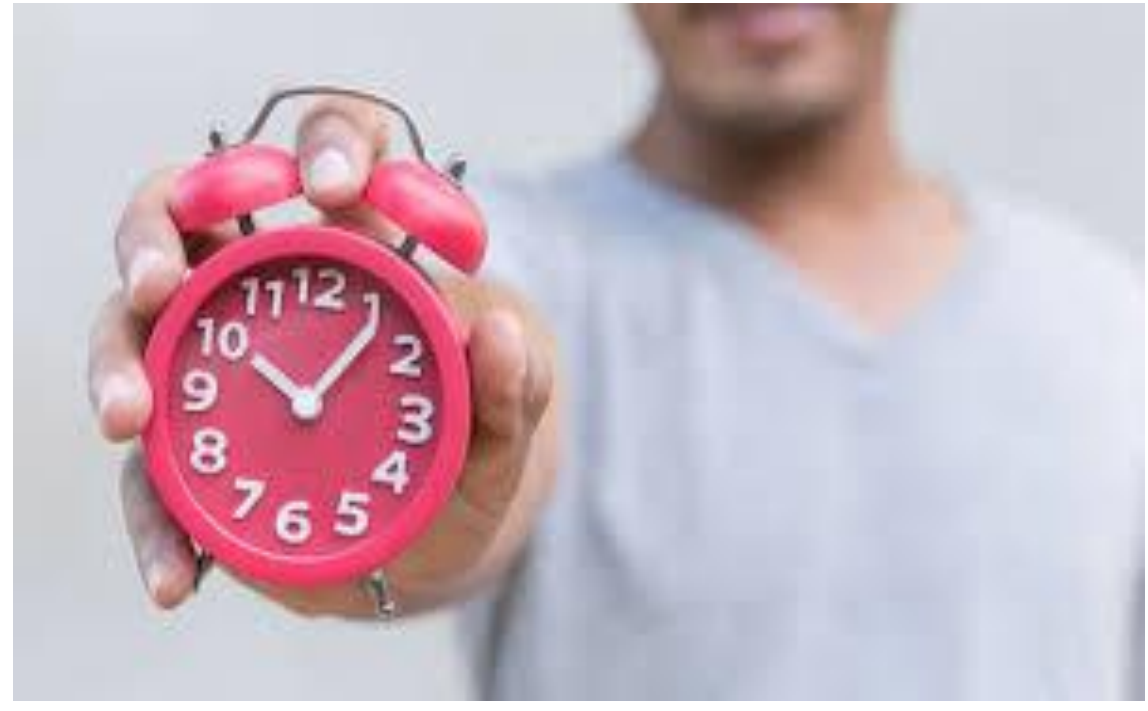

3. CTPS harus dilaksanakan setelah kita menyentuh benda - benda sekitar kita, seperti tangga, gagang pintu tempat-tempat umum, tombol ATM dll. Jika tidak ada sarana/fasilitas untuk CTPS bisa dilakukan cuci tangan memakai handsanitizer.

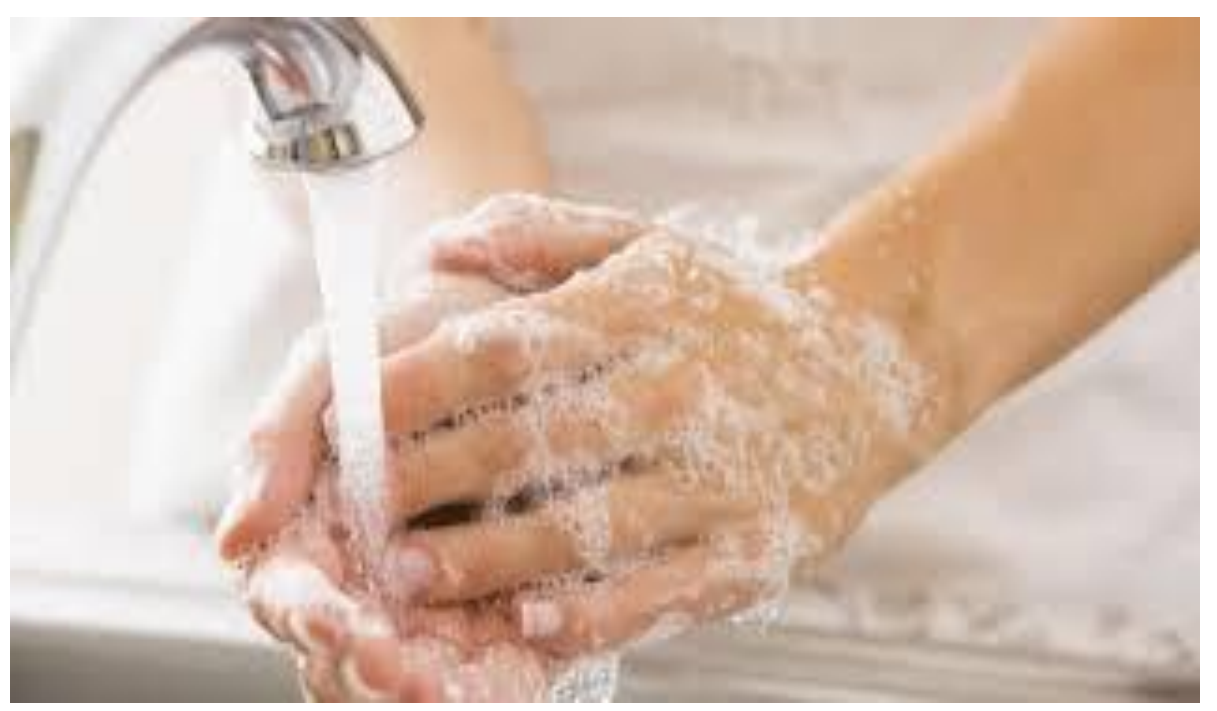

Membersihkan atau mencuci tangan menggunakan cairan pembersih tangan dapat dilakukan dalam situasi tertentu dimana sabun dan air bersih tidak tersedia. Agar hasilnya efektif, cairan pembersih tangan yang digunakan hendaknya mengandung alkohol dengan kadar minimal 60\%. Selain menggunakan produk cairan pembersih tangan berbasis alkohol yang ada di pasaran, kita juga bisa membuat cairan pembersih dengan mengikuti standard dan panduan dari WHO.

Mencuci tangan pakai sabun dan air bersih akan memberi manfaat yang berbeda dari cairan pembersih tangan berbasis alkohol. Sabun dan air bersih dapat menghilangkan semua jenis kuman 
dari tangan, sedangkan cairan pembersih tangan berbasis alkohol hanya bisa mengurangi jumlah kuman tertentu di kulit. Selain itu, cairan pembersih tangan hanya dapat digunakan bila tangan kita tidak kotor dan berminyak. Cairan pembersih tangan berbasis alkohol juga tidak bisa menghilangkan jenis kuman norovirus, Cryptosporidium, dan Clostridioides difficile, serta bahan kimia berbahaya seperti pestisida dan logam berat.

Cuci Tangan Pakai Sabun di Sekolahan. Selalu menjaga kebersihan tangan adalah cara sederhana namun efektif untuk mencegah infeksi. Untuk melindungi diri dari dan pasien dari kuman yang mematikan maupun kuman yang kebal terhadap antibiotik, penyedia layanan kesehatan harus memastikan tangannya bersih dengan cara selalu mencuci tangan pakai sabun dan air bersih mengalir. Bila tangan tidak terlihat kotor, untuk sementara waktu atau jika tidak ada sarana cuci tangan, membersihkan tangan dengan cairan berbasis alkohol dapat dilakukan. Sekolah dan madrasah memainkan peran penting dalam mendidik siswa tentang perilaku kesehatan dan kebersihan. Selain itu selama masa pandemi COVID-19, cuci tangan pakai sabun di sekolah menjadi sangat penting dilakukan guna mencegah penularan COVID-19.

Sebagai bagian dari upaya pencegahan penularan COVID-19 di sekolah, Kementerian Pendidikan dan Kebudayaan telah menerbitkan Surat Edaran No. 3 Tahun 2020 guna mendorong satuan pendidikan untuk:

1. mengoptimalkan peran Unit Kesehatan Sekolah / Madrasah (UKS/M);

2. memastikan ketersediaan sarana CTPS di berbagai area strategis di sekolah;

3. memastikan praktik cuci tangan pakai sabun diterapkan (minimal 40 detik), termasuk mengeringkan tangan (dengan atau tanpa pengering tangan sekali pakai) serta perilaku hidup bersih dan sehat yang relevan lainnya.

Sarana CTPS di sekolah dan madrasah harus memenuhi standar minimum sesuai dengan stratifikasi UKS/M sebagai berikut.

1. Setiap kelas memiliki akses ke fasilitas cuci tangan.

2. Setiap fasilitas cuci tangan harus memiliki sabun dan air mengalir.

3. Setiapfasilitasharusmudahdijangkauolehsemua siswa termasuk yang berkebutuhan khusus. 
Unit Kesehatan di Sekolah (UKS/M) dan guru juga harus mensosialisasikan informasi tentang cara mencuci tangan yang benar dengan metode interaktif dan menyenangkan serta menggunakan materi KIE (Komunikasi, Informasi, dan Edukasi), lagu dan tarian, atau pendekatan ramah anak lainnya.

\section{KESIMPULAN}

Kegiatan PPM dalam memberdayakan Bapak Ibu guru untuk aktivitas yang dapat dilakukan dalam era pandemi telah berjalan dengan baik, dimana tingkat partisipasi bapak ibu guru sangat antusias untuk dapat mengikuti penyuluhan dan kegiatan lainnya. Bapak ibu guru memahami cara menghentikan penularan virus corona dengan menjaga kebersihan sekaligus dapat melakukan cara mencuci tangan pakai sabun dengan benar untuk menghidari tertular virus corona.

\section{UCAPAN TERIMAKASIH}

Jika perlu berterima kasih kepada pihak yang terlibat, misalnya sponsor pengabdian masyarakat, nyatakan dengan jelas dan singkat, hindari pernyataan terima kasih yang berbunga-bunga. 


\section{DAFTAR PUSTAKA}

Fitriani, N.1 (2020). Tinjauan Pustaka Covid- 19: V irologi, Patogenesis, dan Manifestasi Klinis. .Iuin<il Median Moluh<i v<iti, 4(3), 194-20 1.

Gunia, A. (2020). Will the Coronavirus Ever Go Away? Here's What One of the WHO's Top Experts Thinks. Retrieved June 2, 2020, from https://time.com/5S053f/S/will- coronavirusgo-away-world-health-organization/

Habibi, A. (2020) . Normal Baru Pasca Covid- 19. 'Adal<ih . Bulefin f/ukum dii» Kro<;ilon, 4(1), 197-204.

Herliandry, L. D., N urhasanah, N ., Suban , M. E., \& Kuswanto, H. (2020). Pembelajaran Pada Masa Pandemi Covid- 19 . JTP - Jurnal Teknologi Pendidikan, 22(1), 65- 70.

Herdiana, D \& Nurul, S. (2020). Implikasi Tatanan Normal Baru Terhadap Kehidupan Sosial Kemas yarakat an. furnal Ilmi<ih Din mike .So.dial, 4(2), 300-325.

Susilo, A., Rumende, C. M., Pitoyo, C.W., Santoso, W. D., Yulianti, M., Sinto, R., Yunihastuti, E. (2020). Coronavirus Disease 2019: Tinjauan Literatur Terkini. .lurnol Pen s•okit Dalum Irulonrsio , 7(1), 45-67.

Tim Pengabdian Masyarakat UMSIDA (2019). Buku Prnpohñion Mrs ct okot Drew Tehel Ken<im<iton Lie<Llnpun K<ihup<itrn âiñout jn. Sidoarjo: IN MS1DA PRESS 